\title{
Moving towards Practice-Oriented and Research-Based Teacher Education: Challenges of Kosovo and Albania
}

\author{
Eda Vula, ${ }^{\mathrm{a},{ }^{*}}$ Blerim Saqipi, ${ }^{\mathrm{a}}$ Theodory Karaj, ${ }^{\mathrm{b}}$ and Nikoleta Mita ${ }^{\mathrm{b}}$ \\ ${ }^{\mathrm{a}}$ University of Pristina, Kosovo \\ ${ }^{b}$ University of Tirana, Albania
}

\begin{abstract}
The article analyzes the current status, development trends and challenges of teacher education in Kosovo and Albania in their efforts to be aligned with current trends of a more research-based, practice and skills oriented teacher education system. The article compares the provision of pre-service teacher education and draws conclusions related to future development trends of the two countries as they aim to meet the best international standards and practices in shaping pre-service teacher education from a research-based and practice orientation. This article is based primarily on findings from desk research conducted at public universities in Kosovo and Albania, more specifically analyzing the university curricula and other documents related to the provision of teacher education courses. In addition, the research involves the analysis of work completed and documents produced as a result of the 20092011 Trans-European Mobility Program for University Studies (TEMPUS) ${ }^{1}$ Project “Development of Master Study Programs in Education” (DEMED). ${ }^{2}$ The article outlines the similarities and differences of teacher education systems in Kosovo and Albania and emphasizes the need for small countries to cooperate on joint reform that leads to wider regional impact and facilitates mobility of staff and students. Identifying common goals is thus important. The two priority goals for these two countries are: development of practice and research-based teacher education. Conclusions are presented with the intent of findings being extrapolated to similar small, developing countries.
\end{abstract}

\begin{abstract}
Abstrak
Artikel ini menganalisa situasi terbaru, tren pengembangan dan tantangan pendidikan guru di Kosovo dan Albania dalam upaya mengembangkan sistem pendidikan guru berbasis riset plus berorientasi praktek dan ketrampilan. Penulis membandingkan regulasi pendidikan guru pra-jabatan, kemudian menyimpulkan perkembangan kedua negara ke depan dalam mencapai standar internasional dan praktek terbaik untuk pendidikan guru pra-jabatan. Artikel ini merujuk pada penelitian dokumen dari sejumlah universitas negeri di Kosovo dan Albania, secara spesifik menganalisa kurikulum universitas dan dokumen regulasi perkuliahan pendidikan guru. Riset ini juga menganalisa dokumen dan program dari proyek TEMPUS ${ }^{1}$ "Pengembangan Program Master di Pendidikan" (2009-2011). ${ }^{2}$ Memetakan persamaan dan perbedaan sistem pendidikan guru di Kosovo dan Albania, artikel ini menekankan perlunya negara kecil menggagas reformasi bersama dalam rangka kemajuan regional yang lebih luas dan memfasilitasi mobilitas staf dan siswa. Menentukan tujuan bersama menjadi tugas penting. Dua prioritas utama untuk kedua negara ini adalah: pengembangan praktek dan pendidikan guru berbasis riset. Kesimpulan penelitian ini juga berlaku bagi negara kecil dan berkembang lainnya dengan isu serupa.
\end{abstract}

Key Words: Teacher Education, Practice-Oriented Curriculum, Research-Based Curriculum

\section{Introduction}

The initial preparation of teachers is critically important in teacher development and should reflect both expectations the community holds about the role of the teacher and the skills and

*Corresponding author. Address: University of Prishtina, Faculty of Education Building, 10000 Prishtina, Republic of Kosovo.

Email: eda.vula@uni-pr.edu. abilities of individuals who enter the profession. The initial preparation of teachers is one of the most important categories for teacher quality indicators (Goe 2007).

Across the educational systems of the world, rarely few issues have received more attention in recent years than the problem of ensuring that elementary and secondary school classrooms are all staffed with adequately qualified teachers. Teacher education programs and government certification standards often lack adequate rigor, breadth and depth, resulting in high levels of 
underqualified teachers and low student performance. Accordingly, the solution, from this viewpoint, lies in making the entry and training requirements for teachers more restrictive, deeper and more rigorous (Ingersoll 2007).

Since the 1980s, teacher qualification requirements have been increasing, resulting in the universityfication of teacher education, implying that a university degree is a requirement for teacher qualification. "The turbulent processes in a higher education at large and in the global context are bringing further challenges to teacher education as a specific area within higher education" (Hudson and Zgaga 2008, 38). Consequently, numerous reforms and transformations of teacher education institutions happening in most countries are based on their national educational policies and priorities.

"Since 1999, the most distinctive expression of the Europeanization process in the context of higher education has been established as the Bologna Process:' 'building a common European higher education area"” (Hudson and Zgaga 2008, 19). On the other hand, a well qualified profession of teachers is one of the four common European principles ${ }^{4}$ that provide an impetus for developing policies for higher quality and efficiency of education across Europe. Because teacher education is multidisciplinary, this ensures that teachers have extensive subject knowledge, a good knowledge of pedagogy, the skills and competences required to guide and support learners, and an understanding of the social and cultural dimension of education (Council of the European Union 2004).

According to the European Commission's policies, teacher education is put more explicitly on the European agenda, aiming to make the teaching profession a more attractive career choice, to improve the quality of teacher education and to pay attention to initial education in terms of early career support (i.e., induction) and further professional development of teachers. It is crucial that in such situations, the in-service professional development of teachers is not made available for the purpose of covering the gaps of pre-service teacher education but rather serves the purpose of continuous skills development and innovation.

The European Trade Union Committee for Education (ETUCE) (2009) strongly supports the principle that development in education should be evidence-based, and therefore not only is it necessary for prospective teachers to acquire in-depth knowledge of the latest research within their respective subject areas, but initial teacher education must also include a significant component of development work and research training/projects.

\section{Contextual Background}

Kosovo and Albania are located in the West Balkans and they are neighbouring countries. The two countries share many common characteristics including number of inhabitants, cultural and historical elements as well as being at similar economic and social levels of development. The better part of the populations in these countries are Albanians with the same culture and same language (Albanian), which thus make the physical commuting from one country to the other quite easy. Regardless of the fact that there is intensive communication and co-operation between the educational systems of these countries already in place, the countries should further explore the advantages elaborated above to enhance the quality of teacher education.

Based on this background, the present study compares the provision of pre-service teacher education programs in both countries to identify common and different aspects of teacher education in light of development priorities and increased cooperation to move toward best international practices of teacher education in the future.

\section{Kosovo}

Teacher education in Kosovo has undergone significant changes after the 1999 conflict. This did not come only as a need for development of a post-conflict society but also as a need to reform the previous disintegrated and disharmonized two-year teacher education programs in the country so they are compliant with Bologna standards and European best practices (Saqipi 2008). One of the key findings of the Organisation for Economic Co-operation and Development's (OECD) Thematic Review of National Policies for Education carried out in Kosovo in late 2000 was that the concept of teaching as a profession was missing from the teacher training curriculum (OECD 2001). The relationship between "academic" and "professional" courses was mostly "bloodless.” Teacher training in Kosovo was mainly academic and heavily subject-based, and even some educationally relevant subjects, for example subject specific methodology, were taught at a highly academic level (Pupovci 2002). The reform attempts in the last decade have been an attempt to address this situation.

Reform programs were launched to meet the objective of universityfication of teacher education based on the European best practices established in the last decade. Reorganization of teacher education provision in the first and the second cycle of studies (i.e., bachelor's and master's programs, respectively) has been developed in line with the Bologna Process. With continuous efforts and support from European and North American countries in the last decade, positive results have been achieved in the 
direction of reforming the education system in general, and in particular the education of teachers. Teacher education was reformed and the education of teachers for pre-primary, primary and lower secondary schools was put under the umbrella of a single faculty of education, which began operations in 2002. If nothing more, at least teacher education at these levels was operating under common standards. The education of teachers for the upper secondary school is still under academic departments/faculties. The Faculty of Education at the University of Prishtina started to offer master of arts programs in education in 2010 (see Table 1).

Table 1. Teacher Education Programs Offered by the University of Prishtina in Kosovo for the 2010/2011 Academic Year

\begin{tabular}{|c|c|c|c|c|}
\hline & \multicolumn{4}{|c|}{ Faculty of... } \\
\hline & $\begin{array}{l}\text { Educa- } \\
\text { tion }\end{array}$ & $\begin{array}{l}\text { Science and } \\
\text { Mathematics }\end{array}$ & Philosophy & Philology \\
\hline $\begin{array}{l}\text { Kindergarten } \\
\text { Teachers (BA) }\end{array}$ & $1 *$ & 0 & 0 & 0 \\
\hline $\begin{array}{l}\text { Primary Educa- } \\
\text { tion Teachers } \\
\text { (BA) }\end{array}$ & $1^{*}$ & 0 & 0 & 0 \\
\hline $\begin{array}{l}\text { Two-subject } \\
\text { Teachers for } \\
\text { Low Secondary } \\
\text { Education (BA) }\end{array}$ & $8^{*}$ & 0 & 0 & 0 \\
\hline $\begin{array}{l}\text { MA Program in } \\
\text { Education }\end{array}$ & 2 & 0 & 0 & 0 \\
\hline $\begin{array}{l}\text { Teacher of Up- } \\
\text { per Secondary } \\
\text { Education (BA) }\end{array}$ & & 5 & 0 & 1 \\
\hline $\begin{array}{l}\text { Teacher of Up- } \\
\text { per Secondary } \\
\text { Education (MA) }\end{array}$ & & 2 & 1 & 3 \\
\hline Total & 12 & 7 & 1 & 4 \\
\hline
\end{tabular}

*The Faculty of Education has four centers: Gjakova, Gjilan, Prishtina, and Prizren. The campus in Prizren also offers programs in Turkish and Bosnian languages.

\section{Albania}

Albania has a century-long tradition in teacher education starting from 1909. The first pedagogical institute in Albania was established in 1946. During the twentieth century, many teacher education reforms were initiated in this country.

The current program of the Albanian Government aims to reach a European level of education as a necessary condition for the European development of the country, and within this framework has started an educational reform in order to achieve this aim. The Ministry of Education and Science (2009) in Albania has approved the National Strategy for Higher Education that aims, among other objectives, to restructure the higher pedagogical education, to improve pre-service education curricula framework, to change teaching styles, to offer linking systems among schools, to design the architecture of the national curriculum for in-service teacher training, and to introduce an induction and licensing system.

Pre-service training is carried out entirely by universities. The education of teachers varies according to the cycle of studies and type of education program. Seven public universities in Albania offer in total 71 teacher education programs. There are five types of programs: kindergarten teacher, primary education teacher, subject teacher, subject teacher for lower secondary education, and subject teacher for upper secondary education. Teachers of preschool education and primary education are prepared through the bachelor of arts programs. Initial training for kindergarten teachers is provided at five universities. Initial training for primary education teachers is provided at six universities. Subject teachers major in one or two subjects during their bachelor's program before they start their master's program in subject teaching. There is only one bachelor's program for the subject teacher. Five universities offer a master of arts program for the lower secondary education teachers, while four universities provide a master of science program for the upper secondary education teachers. The data are shown in Table 2.

Table 2. Number of Teacher Education Programs in Albania for the 2010/2011 Academic Year

\begin{tabular}{l|c|c|c|c|c|c|c}
\hline \multirow{2}{*}{$\begin{array}{l}\text { Teacher } \\
\text { Education } \\
\text { Program }\end{array}$} & \multicolumn{7}{|c}{ University of... } \\
\cline { 2 - 8 } & Tirana & Elbasan & Shkodra & $\begin{array}{c}\text { Gjiro- } \\
\text { kastra }\end{array}$ & Korça & Vlora & Durres \\
\hline $\begin{array}{l}\text { Kindergarten } \\
\text { (BA) }\end{array}$ & 0 & 1 & 1 & 1 & 1 & 1 & 0 \\
\hline $\begin{array}{l}\text { Primary Educa- } \\
\text { tion (BA) }\end{array}$ & 0 & 1 & 1 & 1 & 1 & 1 & 1 \\
\hline Subject (BA) & 0 & 0 & 0 & 0 & 0 & 0 & 6 \\
\hline $\begin{array}{l}\text { Lower Secon- } \\
\text { dary Education } \\
\text { (MA) }\end{array}$ & 0 & 11 & 10 & 6 & 2 & 3 & 0 \\
\hline $\begin{array}{l}\text { Upper Secon- } \\
\text { dary Education } \\
\text { (MSc, MA) }\end{array}$ & 12 & 0 & 6 & 0 & 2 & 2 & 0 \\
\hline \begin{tabular}{l} 
Total \\
\hline
\end{tabular} & $\mathbf{1 2}$ & $\mathbf{1 3}$ & $\mathbf{1 8}$ & $\mathbf{8}$ & $\mathbf{6}$ & $\mathbf{7}$ & $\mathbf{7}$ \\
\hline
\end{tabular}

Preschool education teachers and primary education teachers need a three-year bachelor's diploma. Lower and upper secondary education teachers need bachelor's diploma (180 credits with study in one or two subjects) and a master's diploma (90-120 credits). Promotion in teaching is based on the quality of the results of the written test organized by the Ministry of Education and Science. Primary and secondary education teachers are promoted after 5-, 10-, and 20-years of teaching experience. The promotion is connected with a salary increase. 
Universities are facing numerous problems in relation to preservice teacher education, mainly in terms of curricula, teaching methodology, teaching practice and research. Due to the lack of national standards, curricula offered by various universities have significant pedagogical differences. Four years ago, universities produced teachers under a four-year system in which student teachers took three to four pedagogical courses such as Introduction to Psychology, Introduction to Pedagogy, General Didactics, and Subject Didactics. The professional component made up only 7-15 percent of the curriculum. As a result, traditional teacher-centered methods prevailed.

Another concern with the pre-service training is the effectiveness of teaching practice. Students apparently have good theoretical knowledge, but they are not well prepared for real work in school settings, both because of the short time of the teaching practice (one month) and an ineffective supervising system.

\section{Pedagogical Training in Teacher Education Programs}

Pedagogical content knowledge is understood as essential knowledge for teachers to transform their disciplinary knowledge into effective teaching. Lee Shulman (1986) introduced the phrase "pedagogical content knowledge" and sparked a new wave of scholarly articles on teachers' knowledge of their subject matter and the importance of this knowledge for successful teaching. In Shulman's theoretical framework, teachers need to master two types of knowledge: (a) content, also known as “deep” knowledge of the subject itself, and (b) knowledge of curriculum development.

In Kosovo, primary teacher education professional courses ${ }^{5}$ constitute 58 percent of the credits under the European Credit Transfer and Accumulation System (ECTS); ${ }^{6}$ in lower secondary it is 37 percent and in upper secondary teacher education only 16 percent of total ECTS credits. The curricula of upper secondary teacher education are in most cases organized around academic disciplines. As shown in Table 3, it is obvious there is a discrepancy between the "academic" and "professional" components at various levels. In most cases, the relationship between the academic discipline and both its development and the school subject do not seem to be well connected, or at least not thought out from a systemic and standardization perspective.

In Albania the educational (or professional) courses are better incorporated in upper secondary teacher education, accounting for 35 percent of the total number of ECTS credits. Initial teacher education programs for the upper secondary level are largely focussed on "academic" courses and generally in one major subject in the two countries.
Table 3. Incorporation of Academic Courses, Professional Courses and Teaching Practice in Teacher Education Programs for the 2010/2011 Academic Year

\begin{tabular}{|c|c|c|c|c|c|c|c|}
\hline \multirow{3}{*}{$\begin{array}{l}\text { Basic } \\
\text { Qualification }\end{array}$} & \multirow{3}{*}{$\begin{array}{c}\text { Number } \\
\text { of ECTS } \\
\text { Credits }\end{array}$} & \multicolumn{6}{|c|}{ Required Credits at University } \\
\hline & & \multicolumn{2}{|c|}{$\begin{array}{c}\text { Academic } \\
\text { Courses }\end{array}$} & \multicolumn{2}{|c|}{$\begin{array}{c}\text { Professional } \\
\text { Courses }\end{array}$} & \multicolumn{2}{|c|}{$\begin{array}{l}\text { Teaching } \\
\text { Practice }\end{array}$} \\
\hline & & KS & $\mathrm{AL}$ & KS & $\mathrm{AL}$ & KS & $\mathrm{AL}$ \\
\hline \multirow{2}{*}{$\begin{array}{l}\text { Teachers of } \\
\text { Primary Edu- } \\
\text { cation }\end{array}$} & 180 & & $44 \%$ & & $47 \%$ & & $9 \%$ \\
\hline & 240 & $30 \%$ & & $58 \%$ & & $12 \%$ & \\
\hline \multirow{2}{*}{$\begin{array}{l}\text { Teachers of } \\
\text { Lower } \\
\text { Secondary } \\
\text { Education }\end{array}$} & 240 & $51 \%$ & & $37 \%$ & & $12 \%$ & \\
\hline & 270 & & $69 \%$ & & $27 \%$ & & $4 \%$ \\
\hline \multirow{2}{*}{$\begin{array}{l}\text { Teachers of } \\
\text { Upper Secon- } \\
\text { dary Education }\end{array}$} & 240 & $81 \%$ & & $16 \%$ & & $3 \%$ & \\
\hline & 300 & & $66 \%$ & & $30 \%$ & & $4 \%$ \\
\hline \multirow{2}{*}{$\begin{array}{l}\text { Educators of } \\
\text { Preschool } \\
\text { Education } \\
\text { (ages 3-6) }\end{array}$} & 180 & & $56 \%$ & & $32 \%$ & & $12 \%$ \\
\hline & 240 & $21 \%$ & & $67 \%$ & & $12 \%$ & \\
\hline
\end{tabular}

KS=Kosovo; AL=Albania

Table 4 shows that the programs are mainly oriented towards general methodology courses. Topics such as diversity, gender equality and inclusion or special needs education are little involved in the initial preparation of teachers.

Table 4. Content of Professional/Education Courses in Both Countries

\begin{tabular}{|c|c|c|c|c|c|c|c|c|}
\hline \multirow{3}{*}{$\begin{array}{l}\text { Topics in } \\
\text { Pedagogical } \\
\text { Courses }\end{array}$} & \multicolumn{8}{|c|}{$\begin{array}{c}\text { Approximate Number of ECTS Credits for } \\
\text { Teachers of... }\end{array}$} \\
\hline & \multicolumn{2}{|c|}{$\begin{array}{l}\text { Primary } \\
\text { Education }\end{array}$} & \multicolumn{2}{|c|}{$\begin{array}{l}\text { Secondary } \\
\text { Education }\end{array}$} & \multicolumn{2}{|c|}{$\begin{array}{c}\text { Upper } \\
\text { Secondary }\end{array}$} & \multicolumn{2}{|c|}{$\begin{array}{c}\text { Preschool Edu- } \\
\text { cation } \\
\text { (ages 3-6) }\end{array}$} \\
\hline & KS & $\mathrm{AL}$ & KS & $\mathrm{AL}$ & KS & $\mathrm{AL}$ & $\mathrm{KS}$ & $\mathrm{AL}$ \\
\hline $\begin{array}{l}\text { Learning } \\
\text { Theories }\end{array}$ & 6 & & 6 & 4 & 6 & 4 & & 4 \\
\hline $\begin{array}{l}\text { Diversity (e.g., } \\
\text { gender, ethics) }\end{array}$ & 6 & 4 & 5 & & 5 & & 6 & 6 \\
\hline $\begin{array}{l}\text { Special Needs } \\
\text { Education / } \\
\text { Teaching }\end{array}$ & 11 & 4 & 6 & & & & 6 & 5 \\
\hline $\begin{array}{l}\text { Teaching } \\
\text { Methodologies }\end{array}$ & 28 & 35 & 5 & 17 & 6 & 17 & 28 & 23 \\
\hline $\begin{array}{l}\text { Student As- } \\
\text { sessment }\end{array}$ & & 4 & 5 & 5 & 5 & 5 & & \\
\hline $\begin{array}{l}\text { Research in } \\
\text { Education }\end{array}$ & & & & 3 & & 3 & & \\
\hline Other* & 6 & & & 7 & & 7 & 6 & \\
\hline
\end{tabular}

KS=Kosovo; AL=Albania

*Lesson planning, problem-based, project-based learning, classroom management, etcetera. 
However, this finding is limited since the researchers studied only the available documents-programs and course descriptions. It is possible that individual course instructors address these themes more in general methodology/education courses. But, the extent and nature of addressing these themes is an instructor's choice. This differs from the policy oriented approach whereby top down policies and instructions ensure that certain aspects of teaching and learning are properly addressed in the delivery of the programs. Comparisons and more in-depth study of the extent to which and in what ways these specific themes are addressed in teacher education curricula remains a subject of separate research. Developing research skills is almost non-existent in the teacher education curricula of two countries.

\section{Practice-Oriented Curriculum}

The relationship between theory and practice in the knowledge base of teaching and in the professional preparation of teachers is a topic of long-standing debate in teacher education. It is one of the key factors in teacher education programs, and the right combination of theory and practice ensures the partnership between school and college or university. Education of teachers is too important to leave only to the teacher educators.

Observations of the current provision of the teaching practice as part of teacher education programs highlight a number of difficulties. Recent studies conducted in some Western Balkan countries show that there is a gap between the theoretical preparation of teachers and the requirements for "new" skills in practice (Zgaga 2006; Hudson and Zgaga 2008). Many teacher education programs do not provide a coherent practice component. The proportion of time spent specifically on professional training and the number of credits for teaching practice varies not only across different countries, but also between departments and faculties within the same university. Table 5, for example, compares the number of required teaching practice credits across education programs in Albania and Kosovo.

Table 5. Required Credits for Teaching Practice for the 2010/2011 Academic Year

\begin{tabular}{lcccc}
\hline & \multicolumn{3}{c}{ Required Credits for Teaching Practice } \\
\cline { 2 - 5 } & Primary & Lower & Upper & Preschool \\
& Education & Secondary & Secondary & Education \\
& Program & Education & Education & Program \\
& Programs & Programs & \\
\hline Albania & 16 ECTS & 10 ECTS & 12 ECTS & 21 ECTS \\
Kosovo & 28 ECTS & 28 ECTS & 6 ECTS & 28 ECTS \\
\hline
\end{tabular}

The percentage of practice credits in teacher education programs in Kosovo and Albania varies from 3-to-4 percent for upper secondary teacher education, 10-to-12 percent for preschool teacher education, 4-to-12 percent for lower secondary teacher education, and from 9-to-12 percent for primary teacher education. The largest difference in terms of the number of ECTS credits are seen in lower secondary schools and preschool teacher education programs.

\section{Kosovo}

In Kosovo, there are no standards for practice teaching for upper secondary teacher programs. At the bachelor's level in the Department of History, all courses-except the Methdology of Teaching History-are "academic" and have a workload of four ECTS credits. This would make it difficult, if not impossible, to embed the teaching practice within such a structure. In the Faculty of Philology, the teaching practice is implemented differently in the various departments, but usually it is brief. In the Faculty of Mathematics and Natural Science, all programs have the same teaching practice standard: four hours per week in the fourth semester. On the other hand, the practice is standardized within the pre-primary, primary, and lower secondary programs offered by the Faculty of Education. The teaching practice in the Faculty of Education at the University of Prishtina is of a developmental nature and starts with two weeks of observation in the first year and ends with an eight-week-long practice where students take the responsibility for teaching and learning in the classroom. The communication between the student teacher, mentor teacher and faculty supervisor is crucial and the guidelines on this and other issues connected to the implementation of the practice are specified in the Teaching Practice Handbook that every student ideally has. Also, before and at the end of each phase of the practice in the Faculty of Education there is an on-campus class; this class serves as a feedback class after the practice. Some other faculties at the University of Prishtina have a block teaching practice implemented consecutively depending on the number of weeks foreseen in the curriculum, usually in the last semester and typically brief, as Table 5 emphasizes.

The quality of the teaching practice depends on skilled mentors. In Kosovo there are teachers trained to be mentors. The Faculty of Education had a training program in 2002-2005 for mentor teachers. But, the number of mentors prepared in the framework of that project was insufficient to accommodate the number of student teachers that drastically increased over the past few years. Now a mentor can be any teacher in a public school. Consistent and careful classroom observations are difficult to organize. Although practice is one of strengths of the Faculty of Education at the University of Prishtina, it presents at the same time a major challenge in terms of proper supervision and ensuring 
a connection with the theoretical preparation of student teachers on campus.

\section{Albania}

Teaching practice in Albania is composed of two kinds of activities: passive observations and active practice. In the framework of the passive observations, students are asked to attend five classes per week in a school. In the framework of the active practice, student teachers are asked to teach five hours per week. Universities sign agreements with the schools for the purposes of the teaching practice. The responsible departments appoint a teacher as a supervisor for 15 students. The evaluation of students is based on the evaluation made by the supervisor and on the quality of the teaching practice report.

There does not seem to exist systematic structures and planned and formalized methods of ensuring a connection between the practice and theory in teacher education programs. Usually, the two are disconnected. Educational courses are taught separately with no formal connection to ensuring the student experiences in schools are reflected upon, discussed, shared and presented to the rest of the class. This is the case for both countries. An exception may be the lower secondary education programs in the Faculty of Education at the University of Prishtina which have some of the practice combined with the teaching methodology classes.

\section{Research-Based Curriculum}

According to ETUCE (2009, 21), "student teachers must acquire theoretical knowledge and skills in research methodologies to organise, implement and analyse research and development work usually within their own classroom or school and elsewhere." The European Union education ministers also emphasized the need for today's teachers to “develop new knowledge and be innovative through engagement in reflective practice and research” (European Union 2007, 4).

Much of the discussion in the literature has been concerned about whether theoretical research work is adequate in teacher education. Wil Meeus, Linda Van Looy, and Arno Libototton (2004) argue that a thesis at the bachelor's level tends to copy the demands of a theory-oriented master's thesis, which often is in the form of a literature study. A master's thesis is supposed to be a contribution to theory building while a bachelor's thesis is first and foremost meant as a learning instrument. Its importance has more to do with personal development and reflective thinking and for this purpose a portfolio is recommended.

The thesis as research work or a more practically oriented work is also considered by G. Handal (1995) who considers two purposes of a thesis: to improve the discipline and to develop the student's knowledge. The former aim leads to formal demands in line with those derived from a research tradition. These, however, are difficult to satisfy within a task such as the thesis. Handal claims that the thesis within teacher education should be treated as a "learning task" and not as a "research task" (11). However, developing the teacher into a researcher is a much more demanding goal (Cochran-Smith and Lytle 1990; Grimmett 1995; Wilson 1995; Baumann 1996; Henson 1996). In the teacher as researcher movement, the teacher does research either independently or in collaboration with a senior researcher. Educational research in Kosovo and Albania is currently not abundant and teachers tend to believe educational research should be left to the academics.

From the review of existing programs, in Kosovo there are only few courses which address research in education or research skill development. It is an elective course in some bachelor's programs in the Faculty of Education that offers limited knowledge on research in educational sciences and a course on scientific research methodology offered in academic units at the University of Prishtina. Two recent master's programs, though, do require students to write an applied research thesis and offer research methods courses.

In Albania, in the previous four-year bachelor's program 95 percent of all student teachers had to take a final written exam to graduate. In 2008, a thesis was introduced as a compulsory element in bachelor's and master's programs. The master's programs in teacher education introduced four years ago require writing a thesis connected to school context and practice. Starting from the 2009-2010 academic year, the component of research has been strengthened and emphasized. All master's programs will realize the aims of the research component through: (a) a course on research in education, (b) integration of teaching with research, and (c) a research master's thesis.

The development of the research component in teacher education was an objective of the TEMPUS-DEMED Project ${ }^{1,2}$ that was realized during 2009-2010. Supported by three universities that belong to the European Union, the University of Pristina and the University of Tirana were able to develop the Thesis Handbook and integrate action research with teaching into their master's programs. The aim was to develop teachers as researchers. However, access to teachers at the master's level remains limited in both countries, and achieving the target of developing teachers as researchers will remain a goal at least for the near future. A manageable way of teaching students basic research skills and understanding can certainly be considered as a way forward. 


\section{Concluding Points}

A priority for the future development of Kosovo and Albania is to develop knowledge and be innovative through reflective practice and research, which the countries can do in collaboration given their similar cultures and educational systems. It is essential that the educational systems empower teachers to become and remain reflective practitioners throughout their careers so they can assess and improve their teaching; doing so will also increase teachers' ability to conduct research themselves and co-operate with research institutions on research projects as part of their teaching career. The models of research must be built upon a concept of teaching as praxis and require teachers both to examine critically the theories they espouse in light of their findings in school and in turn to critically examine their findings in light of theory.

This article supports the idea that the aim of research-based teacher education is to be able to make educational decisions based on rational thought. Achieving such an objective will promote school reform and teachers will become agents of change in their own context. Students' thesis work needs to be related to on-going research at the university and/or development projects in school. In this way, universities promote and push forward research priorities, and students will be able to be involved in the real research life of the institution they belong, with potential for future collaboration as well. The most suitable form of research for education students at the bachelor's level is the action research type of work as it will prepare prospective teachers to examine their professional practice and continually improve teaching and learning in their classrooms.

The movement towards research-based teacher education requires harmonization of programs to allow for implementation of the research-based approach. The current provision of teacher education focuses on the general nature of education courses, however, a future priority should be teacher education focusing on addressing more narrow fields of teachers' work rather than general aspects of teaching and learning.

Teacher educators play a significant role in the sense that teacher education institutions need to have the capacity, commitment and provisions to educate teachers who are able to study and develop their own professional practice on a continuous basis and to find and analyze problems they may face in their future work. The idea is to make student teachers gain deeper insight into academic culture and research as well as into school culture. While access to master's courses remains limited in these countries, emphasizing research skills at the bachelor's level seems to be the best way to move forward from the current situation. In Kosovo, the Ministry of Education is mandating universities to start offering minimum master's level qualification for teachers in the not so distant future. This needs to be taken into consideration during the policy debate while such changes occur

Based on a comparative analysis of the teaching practices in Kosovo and Albania, some conclusions can be drawn which should be taken into consideration for further improvements:

- The teaching practice is a component that should be placed in the development agenda of the two countries. It should not be seen only as meeting a formal requirement of being in school; it should rather be a tool to connect theory and practice and help students conceptualize the reality of the school as perceived through theory learned in class. Therefore, the teaching practice should be seen as an integral part of the teacher education program and not disconnected from the coursework in teacher education.

- The mentoring system is sporadic and non-institutionalized in the sense of having a system of "accrediting" mentors so student teachers are exposed to the best possible practice in public and private schools. Developing a student teaching evaluation policy is needed at the institutional level in order to ensure consistency and transparency, but more importantly to ensure that practice assessment is helping students teachers grow in the profession.

- Establishing a network of schools that can act as practice partners will improve the quality of teaching practice. Enhanced university-school co-operation will contribute to educational research being oriented more toward improving professional practice. Thus universities should find ways to enhance collaboration with schools.

This article has identified the need for the two countries to harmonize teacher education development agendas by (1) focusing on connecting theory to practice through a systematic, formalized, properly supervised and mentored teaching practice component; (2) introducing a research skills training component in teacher education programs; and (3) ensuring that research is connected to the research priorities of the department or university when they are available. Such a harmonized agenda could allow for the sharing of resources and expertise needed to implement such changes and at the same time facilitate student and staff mobility. This will indeed be a significant step towards harmonizing the provision of teacher education in these two Western Balkan countries while adhering to European best practices. 


\section{Notes}

1. The Trans-European Mobility Program for University Studies (TEMPUS) is a European Union program that supports the modernization of higher education in the partner countries of Eastern Europe, Central Asia, the Western Balkans and the Mediterranean region mainly through university co-operation projects.

2. DEMED was a joint project of six universities in the framework of the TEMPUS Program: University Roma Tre, Italy, University of Nottingham (UK), University of Aarhus (Denmark), University of Tirana (Albania), South East European University (Macedonia), University of Pristine (Kosovo). This aims of this project were: to improve existing programs and to establish a new curriculum at the master's level in teacher education and educational sciences in Albania, Macedonia and Kosovo; to create a new model of Master Study Programs in Teacher Education and Educational Sciences; to improve the structure of teaching personnel in relation to educational level and professional competence; and to improve research in education.

3. Initially comprised of 29 signatory countries, the Bologna Process evolved out of a meeting held in Bologna, Italy on 19 June 1999. As of June 2012, it has since grown to include 47 signatory countries. "The overarching aim of the Bologna Process is to create a European Higher Education Area based on international cooperation and academic exchange that is attractive to European students and staff as well as to students and staff from other parts of the world” (Bologna Secretariat 2012).

4. Common European Principles for Teacher Competences and Qualifications is a document issued by the European Commission, Directorate-General for Education and Culture that aims to "support policy makers at the national or regional level by setting out common European principles for teacher competencies and qualifications. These have been devised in response to the challenges laid down in the Joint Interim Report by the European Council and the European Commission on progress towards Education and Training 2010. This report recommended that European common references and principles in a number of areas, including the competences and qualifications of teachers and trainers, should be developed "as a matter of priority” (European Commission 2005, 1).

5. Professional courses are courses that address educational theory and practice including teaching and learning assessment, educational psychology, didactics, etc.

6. The European Credit Transfer and Accumulation System (ECTS) was originally established in 1989 as part of the Erasmus programme to help recognize study abroad credits earned by primarily European students within Europe. ECTS is used by all signatory countries participating in the Bologna Process. ECTS helps facilitate student mobility and recognition of credits received in different contexts throughout the European Higher Education Area.

\section{References}

Baumann, James, F. 1996. "Conflict or Compatibility in Classroom Research.” Educational Researcher 25 (7): 29-36.

Bologna Secretariat. 2012. About the Bologna Process. Brussels: Bologna Secretariat. Available online at: http://www.ond.vlaanderen.be/hogeronderwijs/bologna.

Cochran-Smith, Marilyn, and Susan L. Lytle. 1990. "Research on Teaching and Teacher Research: The Issues that Divide.” Educational Researcher 19 (2): 2-11.

Council of the European Union. 2004. Educational and Training 2010: The Success of the Lisbon Strategy Hinges on Urgent Reforms. Joint interim report of the Council and the Commission on the implementation of the detailed work programme on the follow-up of the objectives of education and training systems in Europe. Brussels: European Commission.

European Commission. 2005. Common European Principles for Teacher Competences and Qualifications. Brussels: European Commission, Directorate-General for Education and Culture.

European Trade Union Committee for Education [ETUCE]. 2009. Teacher Education in Europe: An ETUCE Policy Paper. Brussels: ETUCE. Available online at:

http://etuce.homestead.com/ETUCE_en.html.

European Union. 2007. "Information and Notices: Notices from European Union Institutions and Bodies.” 2007/C 300/09. Conclusions of the Council and of the Representatives of the Governments of the Member States, meeting within the Council of 15 November 2007, on improving the quality of teacher education. Official Journal of the European Union. Brussels: European Union.

Grimmett, Peter. 1995. "Developing Voice through Teacher Research: Implications for Educational Policy.” In Critical Discourses on Teacher Development, ed. John Smyth (pp. 113129). London: Cassel.

Goe, Laura. 2007. The Link between Teacher Quality and Student Outcomes: A Research Synthesis. National Comprehensive Center for Teacher Quality. Available online at: http://www.tqsource.org.

Hudson, Brian, and Paval Zgaga, eds. 2008. Teacher Education Policy in Europe: A Voice of Higher Education Institutions. Umea, Slovenia: University of Umea in co-operation with the 
Centre for Educational Policy Studies, Faculty of Education, University of Ljubljana.

Handal, G. 1995. "Examensarbeten? Handledning?” [“Exam Work? Thesis?”] In Didactica Minima, 9, 2: 6-17.

Henson, Kenneth T. 1996. “Teachers as Researchers.” In Handbook of Research on Teacher Education, 2nd ed., ed. John Sikula, Thomas J. Buttery, and Edith Guyton (pp. 53-64). New York: Macmillan.

Ingersoll, Richard M. 2007. A Comparative Study of Teacher Preparation and Qualifications in Six Nations. Consortium for Policy Research in Education. Available online at: http://www.cpre.org.

Meeus, Wil, Linda Van Looy, and Arno Libotton. 2004. “The Bachelor's Thesis in Teacher Education.” European Journal of Teacher Education 27 (3): 229-321.

Ministry of Education and Science. 2009. Strategjia Kombetara e Arsimit Para u Universitar 2009-2013 [National Strategy for Higher Education 2009-2013]. Tirana, Albania: Ministry of Education and Science. Available online at: www.mash.gov.al.
Organisation for Economic Co-operation and Development (OECD). 2001. "Thematic Review of National Policies for Education - Kosovo.” CCNM/DEELSA/ED(2001)6/REV1. Paris: OECD.

Pupovci, Dukagjin. 2002. “Teacher Education System in Kosovo.” Metodika [Methodology] 3 (5): 125-145.

Saqipi, Blerim. 2008. “Teacher Education in Kosovo: International Influences in Shaping the Teacher Education in Kosovo and Local Obstacles in Making it Work.” Paper presented at the Teacher Education Policy in Europe Conference, Ljubljana, Slovenia, 21-23 February 2008.

Shulman, Lee. 1986. Those Who Understand: Knowledge Growth in Teaching. Educational Researcher 15 (2), 4-14.

Wilson, Suzanne M. 1995. "Not Tension but Intension: A Response to Wong's Analysis of the Researcher/Teacher.” Educational Researcher, 24 (8): 19-22.

Zgaga, Pavel, ed. 2006. The Prospects of Teacher Education in South-East Europe. Ljubljana: Center for Educational Policy Studies, University of Ljubljana. 